Article

\title{
Glass Houses and Friends-and-Neighbors Voting: An Exploratory Analysis of the Impact of Political Scandal on Localism
}

\author{
Franklin G. Mixon, Jr. \\ Center for Economic Education, Columbus State University, Columbus, GA 31907, USA; \\ mixon_franklin@columbusstate.edu
}

Received: 4 July 2018; Accepted: 27 August 2018; Published: 3 September 2018

\begin{abstract}
The 2017 U.S. Senate Special Election in Alabama, which was decided on 12 December 2017, was one of the most contentious and scandal-laden political campaigns in recent memory. The Republican candidate, Roy Moore, gained notoriety during the 2017 campaign when a number of women alleged to national media that as teenagers they were subject to sexual advances by Moore, who was then in his early 30 s and serving as a local assistant district attorney. The process and results of this particular election provide the heretofore unexamined impact of political scandal on localism or friends-and-neighbors voting in political contests. Based on data from the 2017 special election in Alabama, econometric results presented here suggest that a candidate who is embroiled in political scandal suffers an erosion in the usual friends-and-neighbors effect on his or her local vote share. In this particular case, the scandal hanging over Moore eroded all of the friends-and-neighbors effect that would have been expected (e.g., about five percentage points) in his home county, as well as about $40 \%$ of the advantage Moore had at home over his opponent in terms of constituent political ideology.
\end{abstract}

Keywords: friends-and-neighbors voting; localism in elections; reputation capital; political scandal

JEL Classification: D70; D72

\section{Introduction}

The 2017 U.S. Senate Special Election in Alabama, which was decided on 12 December 2017, encompassed one of the most contentious and scandal-laden political campaigns in recent memory. The election was won by the Democratic candidate, Doug Jones, a lawyer from Birmingham. Jones defeated Roy Moore, the Republican candidate from Gadsden, who had previously served as Chief Justice of the Alabama Supreme Court. Given the political intrigue that accompanied the campaign, during which Moore faced accusations of sexual improprieties, the process and results of this particular 2017 election provide an opportunity to explore the impact of political scandal on friends-and-neighbors voting (or localism) in election contests. More specifically, the present study fills a void in the public choice literature on localism (e.g., see Lewis-Beck and Rice 1983; Rice and Macht 1987; Kjar and Laband 2002; Disarro et al. 2007; Mixon 2013) by exploring how political scandal impacts the friends-and-neighbors advantage that typically accrues to local candidates in situations not involving political scandal.

Aside from the possibility that political scandal does not impact friends-and-neighbors voting, scandals, such as that faced by Moore, may lead to intensified support for the local candidate, as his or her constituents refuse to believe accusations of scandal and instead rally behind the candidate. On the other hand, local constituents may find allegations of scandal credible, and as a result they may opt to support the local candidate's rival in an effort to mitigate the higher expected agency costs 
from electing an untrustworthy representative. Results from a decomposition approach presented in this study suggest that the latter effect prevailed in the 2017 U.S. Senate Special Election in Alabama, as the political scandal that hung over Moore during the final weeks of the campaign eroded all the friends-and-neighbors effect that would have been expected (e.g., about five percentage points) in his home county. Moreover, in this case, the harshness of the political scandal reduced, by about $40 \%$, the advantage Moore had at home over his opponent in terms of constituent political ideology.

\section{Conceptual Framework and Prior Literature}

Before turning to the empirical results mentioned above, this section of the study provides both a conceptual framework for studying the impact of political scandal on friends-and-neighbors voting and a review of prior studies on localism in elections. The conceptual framework includes a brief discussion of the agency costs of representative democracy, while the review of prior studies focuses on the stream of literature that includes estimates of the friends-and-neighbors effect in electoral contests in the U.S.

\subsection{Conceptual Framework}

As Kjar and Laband (2002) assert, voters reduce the agency costs of representative democracy simply by electing family members into office or by voting for individuals who have lived for many years in their respective political jurisdictions. ${ }^{1}$ Home grown candidates offer an advantage to voters as they have relatively larger endowments of human capital in the form of information about the conditions of the local political jurisdiction and of the electorate's desires than do more distant candidates (Faith and Tollison 1983; Kjar and Laband 2002). ${ }^{2}$ Moreover, voters face lower search costs with regard to the discovery of candidates' attributes in the case of local candidates. Lastly, given that "firing" representatives is costly, if not impossible (e.g., see Mixon 2000), voters will rationally prefer candidates with longstanding ties to the district as these candidates implicitly put more human and other capital at risk as a Klein and Leffler (1981) type of performance bond than do non-local candidates with fewer ties to the political jurisdiction (Kjar and Laband 2002). As Kjar and Laband (2002) assert, voters understand and appreciate the implied efficiency of casting their ballots in favor of a candidate who has much to lose locally from nonperformance in his or her capacity as an elected official.

In terms of political scandal, such as that faced by Moore in 2017, it may be the case that a candidate's friends and neighbors are unfazed by the allegations, and the effect of localism in this situation is similar to that in elections that are untainted by political scandal. Alternatively, the candidate's constituents may be unwilling to believe the allegations and, in response to the scandal, intensify their support for the local candidate. Thus, in this case, the scandal augments the traditional friends-and-neighbors effect. Lastly, it is also possible that the candidate's constituents do believe the allegations and that they respond by rallying behind his or her political opponent in an attempt to either punish the candidate, in the case of an incumbent, for betraying their trust, or to prevent the candidate, in the case of a challenger, from reaching a position from which to cause them to suffer political harm and/or to engage in costly monitoring efforts (i.e., to be exposed to agency costs).

\subsection{Prior Literature}

Academic research on localism in politics began with the pioneering work of Key and Heard (1949), and extends to a series of more recent empirical studies. In the first of these, Lewis-Beck and Rice (1983) find, using data from U.S. presidential elections from 1884 through to 1980, that candidates receive four percentage points more support from voters in their home states than they do in other states. Later,

See Sass (1992) for an excellent discussion of the costs associated with constitutional choice in representative democracy.

Alternatively, problems associated with asymmetric information are not as severe for friends and neighbors (i.e., local constituents) as they are for more distant constituents. 
Rice and Macht (1987) come close to replicating this result in their analysis of U.S. gubernatorial and Senate elections from 1976 through to 1982, as county-level data in that study suggest a friends-and-neighbors voting effect of about 3.7 percentage points. These two early studies laid the foundation for a twenty-first century renaissance in the academic literature on friends-and-neighbors voting that includes the study by Kjar and Laband (2002). These authors examined election returns from the 1998 election for Alabama's Third Congressional District, finding a friends-and-neighbors voting effect ranging from 8.2 to 12.4 percentage points of the overall vote share. These numbers are larger than that found in Lewis-Beck and Rice (1983), and likely reflect a greater "closeness" between the candidates and constituencies associated with elections in U.S. Congressional districts vis-à-vis those held statewide.

As indicated in Table 1, the study by Kjar and Laband (2002) is followed by a series of studies of U.S. presidential elections. ${ }^{3}$ Mixon and Tyrone (2004), for example, find, in their examination of U.S. presidential elections from 1972 through to 2000, a friends-and-neighbors voting effect ranging from 5.2 to 6.7 percentage points, while Disarro et al. (2007) present a percentage point estimate of 5.1 in their analysis of election returns data from 1880 through to 2004. Additional analyses of U.S. presidential elections from 1972 through to 2004 by Mixon et al. (2008) and Kahane (2009) produce percentage point estimates of the home state effect ranging from 4.9 to 7.7 , and from 2.4 to 9.3, respectively. Lastly, Mixon (2013) takes a novel approach to the subject by exploring home grown-ness in the 1940 and 1944 presidential elections using countywide returns from Georgia, where incumbent U.S. President Franklin D. Roosevelt spent significant portions of his time in Warm Springs seeking warm water therapy for polio. That study finds that in Meriwether County, where Warm Springs is located, and in its bordering counties, Roosevelt's vote share was about 7.8 percentage points greater than it was in Georgia's other counties.

Table 1. Friends-and-neighbors effect estimates from prior studies.

\begin{tabular}{ccc}
\hline Study & Subject & Friends-and-Neighbors Effect $^{\text {a }}$ \\
\hline Lewis-Beck and Rice (1983) & U.S. Presidential Elections, 1884-1980 & 4.0 \\
Rice and Macht (1987) & U.S. Gubernatorial and Senate Elections, 1976-1982 & 3.7 \\
Kjar and Laband (2002) & Alabama's 3rd Congressional District, 1998 & $8.2-12.4$ \\
Mixon and Tyrone (2004) & U.S. Presidential Elections, 1972-2000 & $5.2-6.7$ \\
Disarro et al. (2007) & U.S. Presidential Elections, 1880-2004 & 5.1 \\
Kahane (2009) & U.S. Presidential Elections, 1972-2004 & $2.4-9.3$ \\
Mixon et al. (2008) & U.S. Presidential Elections, 1972-2004 & $4.9-7.7$ \\
Mixon (2013) & U.S. Presidential Elections, 1940-1944 & 7.8 \\
\hline
\end{tabular}

${ }^{a}$ Friends-and neighbors effect is measured in percentage points.

The current study follows Mixon (2013) in extending the literature on friends-and-neighbors voting by analyzing election returns from a statewide race-that of the 2017 U.S. Senate Special Election in Alabama-pitting Republican candidate, Roy Moore, against Democratic candidate, Doug Jones. Of interest here is the intense national focus on the scandal in Moore's personal life, including various allegations of sexual misconduct, which, in some cases, involved a minor. One would expect that the electoral boost from friends-and-neighbors support, or localism, is eroded by political scandal, as some, if not many, of a candidate's local political supporters abandon him or her in response to their concerns related to facing higher agency costs. Thus, if one takes the friends-and-neighbors effect estimated by Mixon et al. (2008) of five percentage points (see Table 1) as a baseline, one would expect political scandal would reduce that to something less than five percentage points. Quantifying this expected erosion is the aim of this study. Before turning to this analysis, the next section of the study offers a primer on the scandalous nature of this particular political contest.

3 As the current study tests elements of friends and neighbors voting in a U.S. election, this particular section focuses only on empirical studies that examine U.S. elections. 


\section{Alabama's 2017 U.S. Senate Special Election: A Primer}

Shortly after taking the oath as U.S. Attorney General in 2017, Alabamian, Jeff Sessions', U.S. Senate seat was turned over to Alabama Attorney General, Luther Strange, and preliminary discussions began regarding a special election to replace Sessions on a permanent basis (Smilowitz 2017). That decision was made by Alabama's Republican Governor, Kay Ivey, in late April of 2017 when 12 December 2017 was chosen as the date for the special election (Andone 2017). Less than one week after Ivey's announcement, Roy Moore, a resident of Etowah County and Chief Justice of Alabama's Supreme Court, resigned from his position and announced his intention to compete against Strange, who, in December of 2016, stated his desire to permanently replace Sessions, even before being nominated to hold the position on a temporary basis (Cason 2016, 2017). ${ }^{4}$

The Republican contest garnered national attention throughout the period leading up to the primary election in September of 2017. That process culminated in an election-eve rally in Alabama, and Moore's victory in the Republican primary (Borchers 2017). Any celebration by Moore and his campaign team was short-lived, however, as Leigh Corfman, a 53 year old customer service representative at a payday loan business, alleged to national media in early November 2017 that as a 14 year old she met Moore, who was in his early 30s and working as a local assistant district attorney, for the first time outside of a courtroom in Etowah County, Alabama. That meeting prompted what Corfman alleged was initiation by Moore of a sexual encounter (McCrummen et al. 2017). Corfman's was not the only allegation of such behavior, as three other women, who were between the ages of 16 and 18 at the time Moore was in his early 30s, told The Washington Post during the weeks leading up to Corfman's allegation that they too had been pursued by Moore (McCrummen et al. 2017).

By 5 December 2017, one week before the special election, at least nine women had accused Moore of inappropriate sexual behavior (Quinn 2017), causing Moore's candidacy to unravel. That trend continued through to 12 December 2017, when Doug Jones, a resident of Jefferson County and an Alabama attorney who had (relatively) quietly won the Democratic primary, defeated Moore in the general election by almost 22,000 votes, taking $50.8 \%$ of the major party vote share in a Republican-leaning state. On 28 December 2017, Ivey certified the special election results, nullifying a legal challenge by Moore, who had not conceded the race (Blinder 2017).

\section{Econometric Model and Estimation Results}

\subsection{Econometric Model}

This study takes an approach to modeling friends-and-neighbors voting that is similar to that in the series of studies, beginning with Kjar and Laband (2002), presented in Table 1. As such, the specification below:

$$
\begin{gathered}
\text { Moore Vote Share }{ }_{i}=\alpha+\beta_{1} \log \text { Per Capita Income }+\beta_{2} \% \text { College Graduate }_{i}+\beta_{3} \% \\
\text { Poverty }_{i}+\beta_{4} \% \text { Black }_{i}+\beta_{5} \text { Electorate Ideolog } y_{i}+\beta_{6} \text { Moore Home }_{i}+\varepsilon_{\mathrm{i}},
\end{gathered}
$$

where the dependent variable, Moore Vote Share ${ }_{i}$, is equal to the two-party vote share (percent) in Alabama county $i$ captured by the Republican candidate, Roy Moore. This specification is proposed as a foundation for a decomposition approach that is discussed later in the study. Among the regressors in (1) are four demographic variables-log Per Capita Income $i, \%$ College Graduate $i, \%$ Poverty $_{i}$, and $\%$ Black $_{i}$. The first of these is the natural logarithm of per capita income in the county, $i$, the second is the percent county $i$ 's population holding a college degree, while the third is the percent of county $i$ 's population living at or below the poverty level. Given the Democratic Party's traditional affiliation with working

4 That nomination process was further contested when, in mid-May of 2017, U.S. Representative Mo Brooks announced his candidacy (Hrynkiw 2017). 
class voters, estimates of $\beta_{1}, \beta_{2}$, and $\beta_{3}$ are expected to be negatively signed. Support for Democratic candidates among black voters is also traditionally high, and more so in the case of this particular election given that a victory by Moore would be seen to further advance U.S. President Donald Trump's political agenda. As such, Black ${ }_{i}$, which is the percent of county i's population that is accounted for by black residents, is expected to retain a negatively-signed parameter estimate.

Next, as a measure of political leaning of the constituents of the county, $i$, Electorate Ideology $i$ is included on the right-hand side of (1). This variable is equal to the 2016 countywide vote share (percent) for incumbent U.S. Senator, Richard Shelby, a Republican, and it serves as a baseline for how conservative the voters are in a given county, $i$. As such, it is expected that the parameter estimate for $\beta_{5}$ will be positive as conservative Alabamians are more likely to support Moore, ceteris paribus. Finally, Moore Home $_{i}$ is a dummy variable equal to 1 if county, i, represents Moore's home county, and 0 otherwise. As indicated earlier, the estimate for $\beta_{6}$ will be greater than zero if local constituents are unfazed by the allegations of scandal, or if they are unwilling to believe such allegations and, in response, intensify their support for Moore. This study posits, however, that the allegations were of such an extreme nature (i.e., inappropriate, and perhaps illegal, sexual behavior) that they were believed by a large portion of the local constituency, who became distrustful of Moore and concerned about the additional agency costs he might impose on them as a U.S. Representative. These concerns, coupled with the smaller gap on a unidimensional ideological spectrum between Republicans and Democrats in a state, such as Alabama (as opposed to states, such as New York or California), it is expected that the estimate of $\beta_{6}$ will be negative, as local constituents turn to Jones.

\subsection{Estimation Results}

To estimate (1), data from Alabama's 67 counties are collected. ${ }^{5}$ Summary statistics (i.e., means and standard deviations) are presented in Table 2. Although not included, the mean of Moore Vote Share $_{i}$ is 54.9, with a standard deviation of 19.2. In terms of the regressors, the average income across the 67 Alabama's counties is about $\$ 40,000$, approximately $16.5 \%$ of each county's population holds a college degree, while about $22 \%$ of the typical county's residents live at or beneath the poverty level. Additionally, about $28.5 \%$ of the typical county's population is accounted for by black residents. Based on the political ideology variable, the state's voters lean conservative in national elections. As indicated in Table 2, the typical countywide election in 2016 produced about a $65 \%$ vote share for the Republican candidate, Richard Shelby.

Table 2. Summary statistics and Pearson correlation coefficients.

\begin{tabular}{|c|c|c|c|c|c|}
\hline Variables & $\begin{array}{c}\text { Means } \\
\text { [S.D.] }\end{array}$ & $\%$ College Graduate & \% Poverty & $\%$ Black & Electorate Ideology \\
\hline $\log$ Per Capita Income & $\begin{array}{l}10.6 \\
{[0.2]}\end{array}$ & +0.633 & -0.898 & -0.644 & +0.608 \\
\hline$\%$ College Graduate & $\begin{array}{l}16.7 \\
{[7.0]}\end{array}$ & $\bullet$ & -0.418 & -0.041 & -0.035 \\
\hline$\%$ Poverty & $\begin{array}{l}22.0 \\
{[6.6]}\end{array}$ & $\bullet$ & $\bullet$ & +0.807 & -0.788 \\
\hline$\%$ Black & $\begin{array}{c}28.6 \\
{[22.3]}\end{array}$ & $\bullet$ & $\bullet$ & $\bullet$ & -0.974 \\
\hline Electorate Ideology & $\begin{array}{c}64.7 \\
{[18.4]}\end{array}$ & $\bullet$ & $\bullet$ & $\bullet$ & $\bullet$ \\
\hline
\end{tabular}

5 Demographic data are collected from us-places.com, alabamapossible.org and al.com. Elections results are collected from al.com and The New York Times. 
Pearson correlation coefficients are also presented in Table 2. These indicate that the variable log Per Capita Income is relatively highly correlated with each of the other four regressors included in the table, and that Electorate Ideology is relatively highly correlated with three of the other four regressors. Additionally, two variables_ \% Poverty and \% Black—display a strongly positive association. As such, OLS estimation of (1) above is likely to exhibit some of the negative effects (e.g., incorrectly signed regression coefficients and/or insignificant regression coefficients) of multicollinearity.

To explore the potential impact of collinearity among some of the variables, Table 3 presents OLS estimation results from three separate restricted specifications of the model in (1) above. Version (1), which includes only log Per Capita Income, \% Poverty, \% Black, and Moore Home, is jointly significant at the 0.01 level, while it produces an $R^{2}$ of 0.909 . In this case, log Per Capita Income is negatively signed and significant, as expected, while both \% Poverty and \% Black retain negatively-signed coefficient estimates, as expected, with the latter reaching statistical significance. ${ }^{6}$ The insignificance of at least one of these two variables, which in this case is \% Poverty, is unsurprising given the relatively large Pearson correlation coefficient between them of +0.807 . Lastly, the variable, Moore Home, is negatively-signed and significant, representing a departure from prior studies discussed above and summarized in Table 1. The result suggests that Moore's vote share in his home county is about 5.2 percentage points lower than that in the other Alabama counties, ceteris paribus.

Table 3. Summary of OLS results.

\begin{tabular}{|c|c|c|c|c|}
\hline Regressors & (1) & (2) & (3) & (4) \\
\hline constant & $\begin{array}{l}350.3 * \\
(4.13)\end{array}$ & $\begin{array}{l}93.61 * \\
(23.50)\end{array}$ & $\begin{array}{l}-11.32 * \\
(-6.92)\end{array}$ & $\begin{array}{l}-4.093 \\
(-0.11)\end{array}$ \\
\hline $\log$ Per Capita Income & $\begin{array}{c}-25.04 \\
(-3.31)\end{array}$ & & & $\begin{array}{l}-1.595 \\
(-0.50)\end{array}$ \\
\hline \% College Graduate & & $\begin{array}{l}-0.719 * \\
(-7.22)\end{array}$ & & $\begin{array}{c}-0.301 * \\
(-3.65)\end{array}$ \\
\hline$\%$ Poverty & $\begin{array}{l}-0.215 \\
(-0.71)\end{array}$ & $\begin{array}{l}-0.213 \\
(-1.17)\end{array}$ & & $\begin{array}{l}0.247 \\
(1.77)\end{array}$ \\
\hline$\%$ Black & $\begin{array}{l}-0.908 * \\
(-17.22)\end{array}$ & $\begin{array}{l}-0.769 * \\
(-14.57)\end{array}$ & & $\begin{array}{l}0.041 \\
(0.90) \\
\end{array}$ \\
\hline Electorate Ideology & & & $\begin{array}{l}1.025^{*} \\
(42.09)\end{array}$ & $\begin{array}{l}1.149 * \\
(17.69)\end{array}$ \\
\hline Moore Home & $\begin{array}{c}-5.231 * \\
(-5.80)\end{array}$ & $\begin{array}{c}-5.899 * \\
(-7.85)\end{array}$ & $\begin{array}{c}-2.985 * \\
(-5.66)\end{array}$ & $\begin{array}{c}-2.765 \text { * } \\
(-8.74)\end{array}$ \\
\hline F-statistic & $155.4^{*}$ & $227.7 *$ & $718.5^{*}$ & $690.6^{*}$ \\
\hline$R^{2}$ & 0.909 & 0.936 & 0.957 & 0.986 \\
\hline
\end{tabular}

Notes: The numbers in parentheses below the parameter estimates above are robust $t$-ratios (White 1980). ${ }^{*}$ denotes the 0.05 level of significance.

Version (2) of Table 3 substitutes \% College Graduate for log Per Capita Income. ${ }^{7}$ Here, \% College Graduate is negatively signed and significant, as expected, while the results for \% Poverty, \% Black, and Moore Home are similar to those found in version (1) of Table 3. The third restricted specification, which is presented in version (3) of Table 3, includes only Constituent Ideology and Moore Home, thus, creating a "political model" (versus the demographic-oriented models in version 1 and 2 of Table 3 )

6 The coefficient estimate attached to \% Black suggests that a four percentage point increase in the percent of a county's population comprised of black residents leads to a 3.5 percentage point decrease, ceteris paribus, in Moore's vote share in that county.

7 The Pearson correlation coefficient between these two variables is +0.633 . This specification is jointly significant at the 0.01 level, while it produces an $R^{2}$ of 0.936 . 
of voting in this 2017 special election. ${ }^{8}$ In this case, the positively-signed and statistically significant parameter estimate attached to Constituent Ideology suggests that Moore benefited, ceteris paribus, from the conservative preferences of the local constituency. Also, in this case, the size of the parameter estimate attached to Moore Home of -2.985 is about one-half of that (in absolute value) found in either version (1) or version (2).

Lastly, the results from the unrestricted specification in (1) are found in the final column of Table 3. This version is jointly significant at the 0.01 level, while it produces an $R^{2}$ of 0.986 , which is quite remarkable for the cross-section data employed here. In terms of individual results, although the result for Electorate Ideology is similar to that in version 3, \% Poverty and \% Black are, unexpectedly, positively related to Moore Vote Share, although neither is significant. Given that the variance inflation factor (VIF) for \% Black is slightly above 20, which is the reported threshold for a problematic degree of multicollinearity in Belsley et al. (1980), multicollinearity plays a role in producing these counterintuitive results. ${ }^{9}$ Next, log Per Capita Income is negatively signed, as expected, but not statistically significant. The Pearson correlation coefficients shown in Table 2 suggest that this result is impacted to some degree by multicollinearity. Finally, the coefficient estimate for Moore Home is, at -2.765 , similar to that found in version 3 , and again runs counter to findings from prior research that are summarized in Table 1.

\subsection{A Decomposition Approach}

The foundational regressions above inform a decomposition of the vote share differences based on county classification (i.e., Moore home vs. other counties) into "explained" and "unexplained" portions. This approach employs a technique often used by labor economists in identifying the effect of gender or race discrimination on wages (see Kitagawa 1955; Blinder 1973; Oaxaca 1973; Oaxaca and Ransom 1999). First, the vote share for Moore in his home of Etowah County is compared to the mean of Moore's vote shares in the remaining 66 countywide election contests. In this case, Moore garnered $59.9 \%$ of the Etowah County vote, while he captured an average of $54.8 \%$ of the total from Alabama's other countywide election contests. As indicated in Table 4, the difference here of 5.1 percentage points (i.e., 59.9 minus 54.8 ) represents the total effect, and it is statistically significant.

Table 4. Decomposition results.

\begin{tabular}{ccccc}
\hline \multicolumn{5}{c}{ Moore Vote Share } \\
\hline Home County & Non-Home Counties & Total Effect & Endowment Effect & Residual Effect \\
\hline 59.9 & 54.8 & $\begin{array}{c}5.1^{*} \\
(p=0.037)\end{array}$ & 8.3 & $-3.2^{+}$ \\
& & & \\
\hline
\end{tabular}

Notes: ${ }^{*}$ denotes the 0.05 level of significance. ${ }^{\dagger}$ denotes that the observation-specific nature of the variable, Moore Home, prevented stochastic treatment of the residual effect.

The "explained" portion of the total effect is referred to as the endowment effect. To estimate its magnitude, Moore Vote Share ${ }_{i}$ is regressed on \% College Graduate ${ }_{i}$ and Electoral Ideology I $_{i}$ using a sub-sample of the data excluding Etowah County (i.e., Moore's home county). ${ }^{10}$ OLS results are provided below:

$$
\begin{aligned}
\text { Moore Vote Share } & =-3.539-0.443 \% \text { College Graduate }+1.019 \text { Electoral Ideology, } \\
(-2.56)(-10.01) & (54.14)
\end{aligned}
$$

8 This specification is jointly significant at the 0.01 level, while it produces an $R^{2}$ of 0.957 .

9 Kennedy (2008) states that harmful multicollinearity is likely present for VIF greater than 10 . Even this rule of thumb applies only to estimates for \% Black and Electorate Ideology.

10 This parsimonious specification is employed to avoid the incorrectly-signed estimates associated with \% Poverty and \% Black. 
where the numbers in parentheses are $t$-ratios. This restricted specification is jointly significant and produces an $R^{2}$ of 0.984 . Substituting the mean values of the regressors from the 66 counties in the sub-sample, this model predicts that Moore would have garnered an average of $54.9 \%$ of vote totals in these 66 individual countywide election contests. When mean values of the regressors from Etowah County are substituted, the model predicts that Moore would have captured $63.2 \%$ of his home county's vote had he been viewed by Etowah County's voters in a way comparable to how he was viewed by voters in the 66 sub-sample counties.

As indicated in Table 4, the difference between these two estimates, referred to as the "explained portion" or the endowment effect, is 8.3 percentage points (i.e., 63.2 minus 54.9), suggesting that endowment advantages accruing to Moore in Etowah County predict he should have performed 8.3 percentage points better in Etowah County than he did in the 66 remaining counties. The remaining difference represents the "unexplained" portion of the total effect and is referred to as the residual effect. In this case, Moore's performance at home exceeded his performance elsewhere by fewer percentage points (i.e., 5.1 percentage points) than would have been predicted (i.e., 8.3 percentage points) by differences in the endowments (regressors) included in (2) above. Thus, as indicated in Table 4 , the residual effect in this case is -3.2 percentage points. ${ }^{11}$

To provide greater context for the estimate of the residual effect, Mixon et al. (2008) use the residual effect from a decomposition approach to estimate a "friends and neighbors" benefit of five percentage points. Using that study as a benchmark, and assuming the Moore-Jones contest were free of scandal, one might have expected that Moore's performance in Etowah County would have exceeded, by five percentage points, what the endowment effect would have predicted. Recalling that the endowment effect suggests that Moore would have performed 8.3 percentage points better at home than elsewhere simply as a result of the difference between his home county's endowments and those of the other counties, then, with the "friends and neighbors" bonus, one would expect Moore's performance in Etowah County to have been 13.3 percentage points better than elsewhere. Instead, Moore's actual home county vote share exceeded that of Jones by only 5.1 percentage points (i.e., the total effect). As such, the political scandal that hampered Moore's candidacy not only erased all of the expected "friends and neighbors" effect (of, perhaps, five percentage points), but it also eroded some of the benefit that should have accrued to Moore as a result of the difference between his home county's endowments and those of the other counties (i.e., the endowment effect).

The decomposition approach suggests that Moore's constituents did believe the allegations that arose during the final weeks of the election, and that they responded by switching their political support to Moore's opponent. Etowah County voters may have decided to pursue this course to prevent Moore from reaching a position, such as that of U.S. Representative, from which to cause them to suffer political harm and/or to engage in costly monitoring efforts (i.e., to be exposed to higher agency costs). This particular election involved a relatively moderate Democratic candidate in Doug Jones, which perhaps explains the intensity of the local electorate's reversal, which erased all of the friends-and-neighbors effect and a portion of the endowment effect. In cases involving scandal where the candidates' platforms exhibit more extreme bimodality (i.e., they are not as closely associated as in a state such as Alabama), complete erosion of the benefits of localism may not occur. In any case, the exploration of the impact of political scandal on friends-and-neighbors voting undertaken in this study indicates that this genre of the public choice literature is perhaps under-theorized, thus, opening up avenues for future research.

11 Treating the residual effect stochastically, as is done with the total effect, requires subtracting the SSE from an OLS regression of (2) using the full sample from the SSE from an OLS regression of (2) using the full sample that also includes Moore Home and interaction terms involving Moore Home and the other two regressors, \% College Graduate and Electoral Ideology. In this particular case, however, stochastic treatment of the residual effect was prevented by estimation issues associated with the observation-specific nature of Moore Home. 


\section{Concluding Comments}

The 2017 U.S. Senate Special Election in Alabama-a contest between Democratic candidate, Doug Jones, a lawyer from Birmingham, and Roy Moore, the Republican candidate from Gadsden who had previously served as Chief Justice of the Alabama Supreme Court-was one of the most scandal-laden political contests in American history. During the last few months of the campaign, a number of women alleged to national media that as teenagers (as young as 14) they were subjected to sexual advances by Moore, who was then in his early 30s and working as an assistant district attorney. With only one week left in the fall 2017 campaign, the number of such accusers stood at nine, as Moore was living in a proverbial glass house while his campaign for the U.S. was unraveling.

This study addresses a void in the literature in this regard by presenting an econometric exploration of the countywide vote shares from this particular election, suggesting that the usual friends-and-neighbors, or localism, advantage that accrues to the local candidate in an election is eroded when that candidate is embroiled in political scandal. In fact, results from a decomposition approach presented in this study suggest not only that all the usual friends-and-neighbors effect is lost due to the presence of a major political scandal, but that almost one-half of the benefit of political ideology alignment that is expected to accrue to the local candidate is also eroded due to the scandal. That Jones eventually defeated Moore in the 2017 special election, even in Republican-leaning Alabama, attests to the deleterious effects of a scandal-induced erosion in friends-and-neighbors voting as a way of mitigating the agency costs faced by a constituency in a representative democracy.

Funding: This research received no external funding.

Conflicts of Interest: The author declares no conflicts of interest.

\section{References}

Andone, Dakin. 2017. Alabama to Hold Special Election to Replace Sessions in Senate. CNN Politics. April 21. Available online: https:/ /www.cnn.com/2017/04/20/politics/alabama-special-election-us-senate/index. html (accessed on 29 August 2018).

Belsley, David A., Edwin Kuh, and Roy E. Welsch. 1980. Regression Diagnostics: Identifying Influential Data and Sources of Collinearity. New York: John Wiley \& Sons.

Blinder, Alan S. 1973. Wage Discrimination: Reduced Form and Structural Estimates. Journal of Human Resources 8: 436-55. [CrossRef]

Blinder, Alan. 2017. Alabama Certifies Jones Win, Brushing Aside Challenge from Roy Moore. The New York Times, December 28.

Borchers, Callum. 2017. Bannon Beat Trump in Alabama (Kind of). The Washington Post, September 27.

Cason, Mike. 2016. Luther Strange Announces he is Running for Sessions' Seat. al.com, December 6.

Cason, Mike. 2017. Roy Moore Running for Senate, Resigns from Supreme Court to Challenge Luther Strange. al.com, April 26.

Disarro, Brian, Jillian Barber, and Tom W. Rice. 2007. The Home State Effect in Presidential Elections: Advances in the Study of Localism. Presidential Studies Quarterly 37: 558-66. [CrossRef]

Faith, Roger L., and Robert D. Tollison. 1983. Voter Search for Efficient Representation. Research in Law and Economics 5: 211-24.

Hrynkiw, Ivana. 2017. U.S. Rep. Mo Brooks Announces Candidacy for Senate, will Speak Across Alabama Monday. al.com, May 15.

Kahane, Leo H. 2009. It's the Economy, and then Some: Modeling the Presidential Vote with State Panel Data. Public Choice 139: 343-56. [CrossRef]

Kennedy, Peter. 2008. A Guide to Econometrics. Malden: Blackwell Publishing.

Key, Valdimer Orlando, and Alexander Heard. 1949. Southern Politics in State and Nation. Knoxville: Alfred A. Knopf.

Kitagawa, Evelyn M. 1955. Components of a Difference between Two Rates. Journal of the American Statistical Association 50: 1168-94. 
Kjar, Scott A., and David N. Laband. 2002. On 'Home-Growness' in Politics: Evidence from the 1998 Election for Alabama's Third Congressional District. Public Choice 112: 143-50. [CrossRef]

Klein, Benjamin, and Keith B. Leffler. 1981. The Role of Market Forces in Assuring Contractual Performance. Journal of Political Economy 89: 615-41. [CrossRef]

Lewis-Beck, Michael S., and Tom W. Rice. 1983. Localism in Presidential Elections: The Home State Advantage. American Journal of Political Science 27: 548-56. [CrossRef]

McCrummen, Stephanie, Beth Reinhard, and Alice Crites. 2017. Woman Says Roy Moore Initiated Sexual Encounter when She was 14, He was 32. The Washington Post, November 9.

Mixon, Franklin G., Jr. 2000. The control of politicians within a constitutional framework: The case of state-level recall provisions. Applied Economics 32: 81-89. [CrossRef]

Mixon, Franklin G., Jr. 2013. Warm Springs Ran Deep: Friends-and-Neighbors Voting in the U.S. Presidential Elections of 1940 and 1944. Journal of Politics and Law 6: 105-15. [CrossRef]

Mixon, Franklin G., Jr., E.W. King, and M.L. Lawing. 2008. Modeling the Impact of Localism in U.S. Presidential Elections. Journal of Public Finance and Public Choice 26: 3-18.

Oaxaca, Ronald. 1973. Male-Female Wage Differentials in Urban Labor Markets. International Economic Review 14: 693-709. [CrossRef]

Oaxaca, Ronald L., and Michael R. Ransom. 1999. Identification in Detailed Wage Decompositions. Review of Economics and Statistics 81: 154-57. [CrossRef]

Quinn, Melissa. 2017. Roy Moore Spokeswoman: Voters must Remember there are Women who have not Accused the Judge of Any Sexual Misconduct. Washington Examiner, December 5.

Rice, Tom W., and Alisa A. Macht. 1987. Friends and Neighbors Voting in Statewide General Elections. American Journal of Political Science 31: 448-52. [CrossRef]

Sass, Tim R. 1992. Constitutional Choice in Representative Democracies. Public Choice 74: 405-24.

Smilowitz, Elliot. 2017. Alabama Attorney General Appointed to Sessions's Senate Seat. The Hill. February 9. Available online: http://thehill.com/homenews/senate/318660-ala-ag-luther-strange-appointed-tosessionss-senate-seat (accessed on 29 August 2018).

Mixon, Franklin G., and J. Matthew Tyrone. 2004. The 'Home Grown' Presidency: Evidence on Localism in Presidential Voting, 1972-2000. Applied Economics 36: 1745-49. [CrossRef]

White, Halbert. 1980. A Heteroskedasticity-Consistent Covariance Matrix Estimator and a Direct Test for Heteroskedasticity. Econometrica 48: 817-38. [CrossRef] 